\title{
C-Peptide responses after meal challenge in mice transplanted with microencapsulated rat islets
}

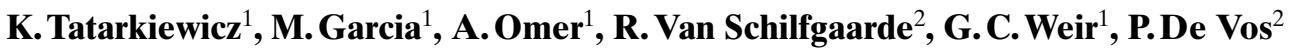 \\ ${ }^{1}$ Research Division, Joslin Diabetes Center, Harvard Medical School, Boston, Massachusetts, USA \\ ${ }^{2}$ Department of Surgery, University of Groningen, Groningen, Netherlands
}

\section{Abstract}

Aims/hypothesis. This study aimed to assess a response of microencapsulated rat islets to a meal challenge after being transplanted intraperitoneally into diabetic mice.

Methods. Microencapsulated rat islets or control naked syngeneic mouse islets were transplanted intraperitoneally into mice with streptozotocin-induced diabetes. Meal challenges were done 3, 6 and 9 weeks after transplantation. Glucose-induced insulin secretion from microencapsulated islets before and after transplantation was assessed in vitro.

Results. Within the first week, all animals transplanted with either microencapsulated rat islets or with syngeneic murine islets became normoglycaemic $(<11 \mathrm{mmol} / \mathrm{l})$. At 4 and 6 weeks, body weight was less than normal in the non-diabetic control mice. Mice with the encapsulated rat islets had lower fasting glucose concentrations and more rapid glucose clearance after a meal challenge than the control mice. The group of mice with transplanted syngeneic islets had similar glucose profiles to control mice, except for slightly accelerated glucose clearance. The $\mathrm{C}$ peptide responses of mice with either microencapsulated or naked islets were clearly lower than the controls. An increase of $\mathrm{C}$ peptide appeared as early as $20 \mathrm{~min}$ in the plasma of the group with encapsulated islets, but this was considerably slower than in the other two groups. Microencapsulated rat islets retrieved 9 weeks after transplantation did not lose their ability to respond to glucose, but their output was less than half of the pretransplant control islets. Conclusion/interpretation. The delivery of $\mathrm{C}$ peptide and presumably the accompanying insulin are delayed by restrictions of the capsules and the peritoneal location. However, this delay in reaching peripheral target organs does not prevent microencapsulated grafts from efficiently clearing glucose after a meal. [Diabetologia (2001) 44: 646-653]

Keywords Microencapsulation, transplantation, pancreatic islet, $\mathrm{C}$ peptide, meal challenge, diabetic mice.
For transplantation of pancreatic islets into patients with Type 1 (insulin-dependent) diabetes mellitus, microencapsulation could provide protection against immune destruction. Such protection has been dem-

Received: 21 November 2000 and in revised form: 18 January 2001

Corresponding author: G.C. Weir, MD, Section of Islet Transplantation and Cell Biology, Research Division, Joslin Diabetes Center, One Joslin Place, Boston, MA 02215, USA Abbreviations: STZ, Streptozotocin; KRH, Krebs-Ringer Hepes buffer, GLP-1, glucagon-like peptide 1. onstrated in several animal models, in which random glucose concentrations have been maintained in the normal range for extended periods of time: in rodents [1-8], dogs [9,10], or cynomologus monkeys [11]. At present, it has only been proved practical to place microcapsules into the peritoneal cavity but it is not clear if this site allows adequate exchange of nutrients, metabolites and insulin between the encapsulated islets and the systemic circulation. To our knowledge, there are few studies of glucose regulation by transplanted microencapsulated islets and these mostly describe only glucose concentrations without providing information about corresponding insulin 
secretion. A previous study from our group, which evaluated rats with microencapsulated islet allografts with an intravenous glucose tolerance test and a meal challenge, showed a lack of insulin responses and slower clearance of blood glucose compared to normal animals [12]. Improvement of biocompatibility of microcapsules did not improve glucose clearance [13]. Insulin infusion into the peritoneal cavity, which was intended to mimic insulin release from microcapsules, was followed by a sluggish rise of insulin in the peripheral circulation [14]. These results suggest that insulin had been secreted into the peritoneal cavity but probably in a manner that adsorption by local tissues prevented insulin from reaching the peripheral concentrations in detectable amounts. In contrast to our previous results, plasma insulin responses have been found in rats transplanted with microencapsulated islets, but this response was impaired when compared to normal animals and the authors did not exclude regeneration of the host pancreas [15].

We assessed how beta cells in microencapsulated rat islets respond to a meal challenge after intraperitoneal transplantation into diabetic mice. The challenges were done at 3,6 and 9 weeks after transplantation and instead of measuring insulin, we assessed $\mathrm{C}$ peptide, which is released in equimolar concentrations with insulin and does not undergo hepatic extraction [16]. Glucose-induced insulin secretion was carried out in vitro to compare the response of microencapsulated islets before transplantation and after retrieval at the end of the study.

\section{Methods}

Animals. Male B6AF 1 mice (Jackson, Bar Harbor, Me., USA) aged 6 to 7 weeks were made diabetic with i.p. injections of streptozotocin (STZ) $(180 \mathrm{mg} / \mathrm{kg}$ body weight, Sigma, St. Louis, Mo., USA) freshly dissolved in citrate buffer $\mathrm{pH} 4.5$. Animals with blood glucose concentrations above $19.4 \mathrm{mmol} / \mathrm{l}$ were used as transplant recipients. Male Sprague Dawley rats (Taconic, Germantown, N.Y., USA) or male $\mathrm{B} 6 \mathrm{AF}_{1}$ mice were used as donors. Non-fasting blood glucose concentrations of all animals and body weights were measured on the day of transplantation and then weekly for next 9 weeks. Blood glucose concentrations were measured with a One Touch portable glucometer (Lifescan, Milpitas, Calif., USA). Of note, blood glucose values obtained with this method are about $40 \%$ lower than plasma concentrations found with standard glucose oxidase techniques [17]. Graft failure was recognized when blood glucose surpassed $11 \mathrm{mmol} / \mathrm{l}$ on two consecutive measurements. All animal procedures were approved by the Animal Care Committee of the Joslin Diabetes Center.

Islet isolation. Rat and mouse islets were isolated with a technique described elsewhere [18]. Briefly, 1 to $2 \mathrm{mg} / \mathrm{ml}$ of a collagenase P (Boehringer Mannheim, Indianapolis, Ind., USA) solution was injected into the pancreatic duct, and the pancreas was digested for $19 \mathrm{~min}$ at $37^{\circ} \mathrm{C}$; islets were then separated from the exocrine tissue using discontinuous density gradient centrifugation with Histopaque-1077 (Sigma Chemical, St.
Louis, Mo., USA). Islets with diameters of 50 to $250 \mu \mathrm{m}$ were hand-picked, counted, and cultured for 1 to 2 days in RPMI1640 containing $10 \mathrm{mmol} / \mathrm{l}$ glucose and supplemented with $10 \%$ fetal calf serum, $100 \mathrm{U} / \mathrm{ml}$ penicillin, and $100 \mathrm{mg} / \mathrm{ml}$ streptomycin (all from Mediatech, Herndon, Va., USA).

Microencapsulation. Before encapsulation, alginate (40\% guluronic acid and $60 \%$ mannuronic acid, Keltone LV, Kelco International, London, UK) was purified according to a method described elsewhere [13]. Microcapsules were produced using a $3 \%$ alginate solution [13], this being a concentration that provides the viscosity required to provide mechanically strong and uniformly spherical capsules; it also minimizes the effect of swelling and shrinking on the formation of inadequate capsules [19]. Before encapsulation, islets were washed with culture medium and then with $\mathrm{Ca}^{++}-$free Krebs-Ringer HEPES Buffer (KRH). The pellet of islets was suspended in sterile filtered alginate and transferred to an air-driven droplet generator. The alginate solution containing 2000 islets/ml was extruded through a blunted 23-gauge needle with an airstream pressure of 9 to $10 \mathrm{~cm} \mathrm{H}_{2} \mathrm{O}$ to form droplets, which were instantly gelled in $100 \mathrm{mmol} / 1 \mathrm{CaCl}_{2}$. The alginate beads were then coated with $0.1 \%$ Poly-L-lysine (Sigma, mol. wt. 15000-30000) for $10 \mathrm{~min}$ followed by $5 \mathrm{~min}$ incubation in a 10 times diluted alginate solution and finally triple washed with KRH. The diameter of microcapsules was in the range of $600 \mu \mathrm{m}$ to $800 \mu \mathrm{m}$. It has been shown previously, that capsules prepared with our method were not permeable to substances larger than 100000 $\mathrm{M}_{\mathrm{r}}[20]$.

Transplantation and retrieval of microcapsules. Recipient mice were anaesthetized with Metofane (Schering-Plough Animal Health, Union, N.J., USA). The microcapsules (volume of $0.4-0.5 \mathrm{ml}$ ) were suspended in $2 \mathrm{ml}$ of $\mathrm{KRH}$ and injected into the peritoneal cavity with a 16-gauge cannula via a small incision $(3 \mathrm{~mm})$ in the linea alba. The muscle layer of the abdomen was closed with a suture and the skin layer was closed with surgical clips.

Nine weeks after transplantation, peritoneal lavage was performed by infusing $5 \mathrm{ml}$ of $\mathrm{KRH}$ through a $2 \mathrm{~cm}$ incision into peritoneal cavity with subsequent flushing of the abdomen above a $50 \mathrm{ml}$ centrifuge tube. The abdominal cavity was then flushed two to three times with KRH.

Samples of microcapsules were fixed in $4 \%$ paraformaldehyde, embedded in paraffin and stained with haematoxylin.

Experimental groups. Two experimental groups and one control group were followed for 9 weeks: (1) STZ-diabetic mice transplanted intraperitoneally with 1000 xenogeneic microencapsulated rat islets; (2) STZ-diabetic mice transplanted intraperitoneally with 1000 syngeneic murine non-encapsulated islets; (3) Age-matched normal non-diabetic mice.

Meal Challenge. Three, 6 and 9 weeks after transplantation animals were fasted overnight $(15 \mathrm{hr})$ and then given food pellets for $10 \mathrm{~min}$ (Mouse Chow 9F containing 20\% protein, $9 \%$ fat, $3 \%$ fiber, $6.5 \%$ ash, and $2.5 \%$ minerals; Purina Mills, Richmond, Ind., USA). To avoid competition for food, each mouse was subjected to a meal challenge in a separate cage. To obtain plasma, blood samples from snipped tails were collected into heparinized capillary tubes before food intake, and 20,60 and 120 min thereafter. For $\mathrm{C}$ peptide measurement, plasma samples were stored at $-80^{\circ} \mathrm{C}$ prior to radioimmunoassay (Linco, St. Charles, Mo., USA). Radioimmunoassay kits were modified for small blood samples by reducing the manufacturer's recommended sample and diluent volumes by two; from $100 \mu \mathrm{l}$ to $50 \mu \mathrm{l}$. The cross-reactivity of antibodies used in assay 
was $100 \%$ for rat and mouse $\mathrm{C}$ peptides. Rat $\mathrm{C}$ peptide was used for standard concentrations.

Insulin secretion in vitro. Glucose-induced insulin secretion was studied in two groups of microencapsulated islets: those cultured for 4 days after encapsulation and those retrieved from animals by peritoneal lavage 9 weeks after transplantation. Samples of handpicked non-overgrown microcapsules containing a total of 10 islets with 100 to $150 \mu \mathrm{m}$ diameter were collected into $12 \mathrm{~mm}$ cell culture inserts with $3.0 \mu \mathrm{m}$ pore membrane (Millicell-PC, Millipore Corporation, Bedford, Ma., USA). Before glucose stimulation, microcapsules containing islets were washed twice with RPMI containing no glucose by transferring them in cell culture inserts to wells containing fresh medium. After 30 min preincubation in RPMI at a glucose concentration of $5.6 \mathrm{mmol} / \mathrm{l}$, capsules were moved to wells containing RPMI with either $5.6 \mathrm{mmol} / \mathrm{l}$ glucose, $16.7 \mathrm{mmol} / \mathrm{l}$ glucose or $16.7 \mathrm{mmol} / \mathrm{l}$ glucose supplemented with $10 \mathrm{mmol} / \mathrm{l}$ theophylline. After a $60 \mathrm{~min}$ incubation, inserts with microcapsules were removed and media were collected and frozen at $-20^{\circ} \mathrm{C}$ pending insulin measurement with radioimmunoassay using rat insulin standards (Linco). The same procedure was applied to control non-encapsulated rat islets obtained from the same isolation cultured under the same conditions for 4 days.

Statistical analysis. Results are presented as means \pm SEM. For statistical comparison, the unpaired, paired Student's $t$-test or analysis of variance (ANOVA) with PLSD Fisher test were used. Differences were considered to be statistically significant if the $p$ value was less than 0.05 .

\section{Results}

Transplantation and retrieval of microcapsules. All animals transplanted with either microencapsulated rat islets or with syngeneic murine islets became normoglycaemic $(<11 \mathrm{mmol} / \mathrm{l})$ within the first week after transplantation. Blood glucose concentrations remained stable for the rest of the study in 7 of 11 mice transplanted with microencapsulated rat islets. Two grafts failed, probably because of substandard quality of the islets, which fits with the poor performance of islets from these batches maintained in tissue culture. The other two grafts were probably unsuccessful because of severe cellular overgrowth that could have been caused by infection introduced during transplantation. The rejection time for SD rat islets transplanted into $\mathrm{B} \mathrm{AF}_{1}$ mice in our previous study was $14 \pm 1$ days [21]. For mice transplanted with syngeneic islets, 5 out of 6 remained normoglycaemic (one mouse became hyperglycaemic 2 weeks after transplantation). The blood glucose profiles of mice with stable grafts are shown in Figure 1A. During the first 2 weeks after transplantation, mice with transplanted microencapsulated rat islets had glucose concentrations of $4.1 \pm 0.2 \mathrm{mmol} / 1$ and $4.6 \pm 0.6 \mathrm{mmol} / \mathrm{l}$ at 1 and 2 week, respectively, which were lower than concentrations of normal control mice $(6.8 \pm 0.2 \mathrm{mmol} / \mathrm{l}$ and $6.8 \pm 0.3$, respectively) $(p<0.01)$. Mice with naked syngeneic islets were in-
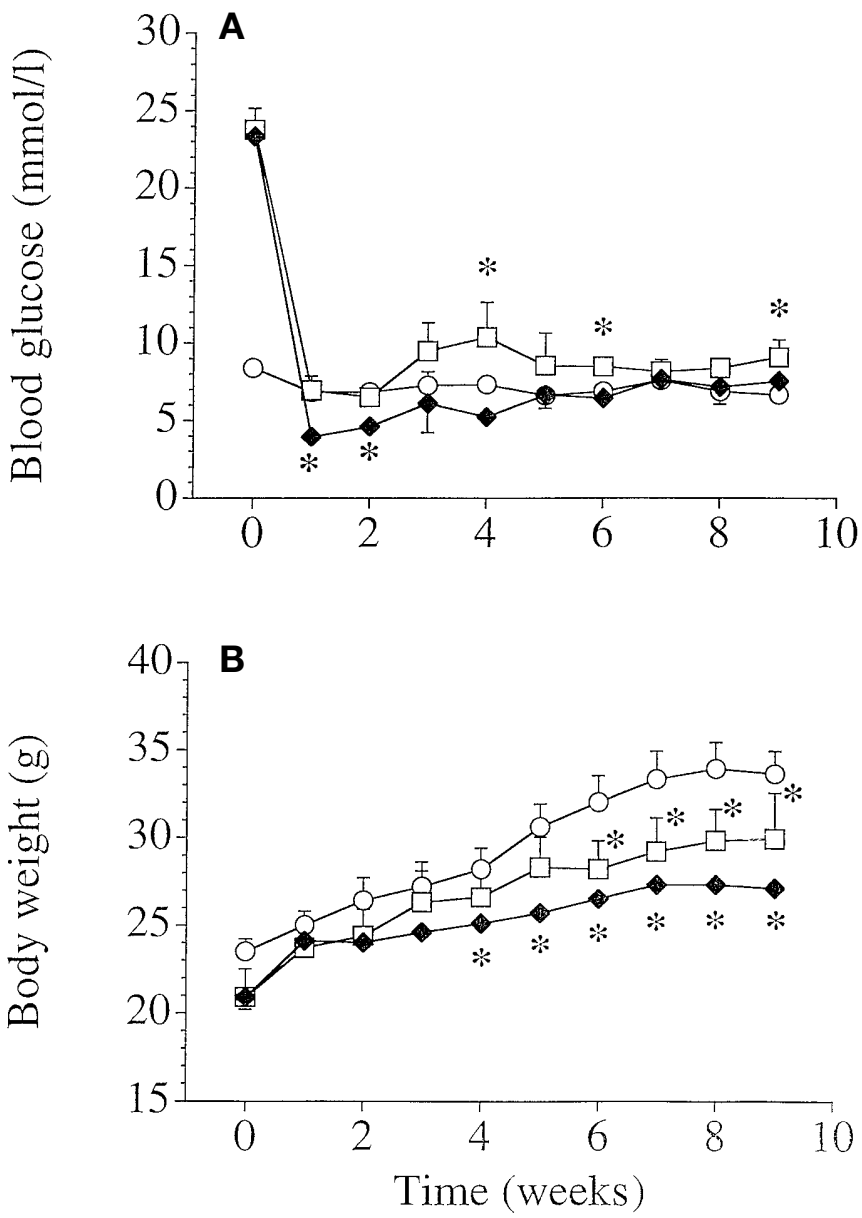

Fig. 1(A, B). Non-fasting blood glucose concentrations (A) and body weights $(\mathbf{B})$ of STZ diabetic $\mathrm{B} \mathrm{AF}_{1}$ mice transplanted intraperitoneally with either microencapsulated xenogeneic rat islets $(\bullet)(n=7)$ or syngeneic non-encapsulated mouse islets $(\square)(n=5)$. As controls, normal non-diabetic $\mathrm{B} \mathrm{AF}_{1}$ mice were used $(\bigcirc)(n=6)$. Data are presented as means \pm SEM; Standard error bars for the group of animals transplanted with microcapsules were very small and therefore overlapped with the plot symbols. $* p<0.05$ vs. normal mice

clined to have higher glucose concentrations than normal controls 3 weeks after transplantation. This tendency persisted for the rest of the study reaching a statistical difference at several time points $(4,6$, and 9 weeks, $p<0.02$ ).

At the beginning of the experiments, diabetic mice were slightly lighter than normal controls (Fig. 1B). After early weight gain, the mice with either intraperitoneal transplanted islets or encapsulated islets had statistically significant lower body weight than the normal control mice.

As measured by volume, most of the capsules could be retrieved by peritoneal lavage $(60-100 \%$ of the initial volume). Microscopic evaluation showed that the fraction of fully overgrown capsules varied from 9 to $48 \%$ of the total. Histology has shown that the cellular overgrowth did not necessarily accompany a lack of surviving beta cells inside the capsules 


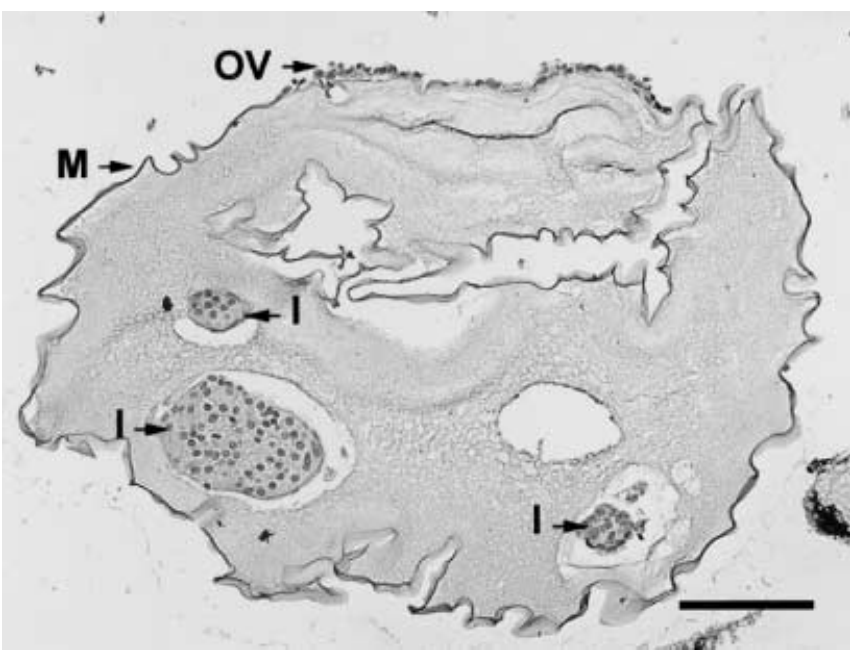

Fig. 2. Alginate-polylysine microencapsule containing rat islets retrieved 9 weeks after transplantation into STZ-diabetic mouse ( $5 \mu \mathrm{m}$ paraffin-embedded histological section, haematoxylin stain). $\mathrm{M}=$ membrane; $\mathrm{I}=$ islet; $\mathrm{OV}=$ layer of cells overgrowing the capsule; magnification bar $=100 \mu \mathrm{m}$

(Fig.2). In fact, in some non-overgrown microcapsules, only remnants of islets could be seen.

Meal challenge. Animals tolerated the overnight fast very well and, after receiving food pellets, ate without hesitation. Plasma glucose values and areas under the curve (AUC) after food intake for all experimental groups at three different time points after transplantation are shown in Table 1. Glucose profiles at 9 weeks (Fig. 3) provide an example of the patterns, which are similar to 3 and 6 weeks. The results for the group with the encapsulated rat islets are strikingly different from those of the other two groups. The fasting glucose concentrations of the mice with encapsulated rat islets were clearly lower at all time points. This phenomenon might have been caused by differences in fasted and fed blood glucose concentrations in mice and rats. Normal $\mathrm{B} \mathrm{AF}_{1}$ mice have

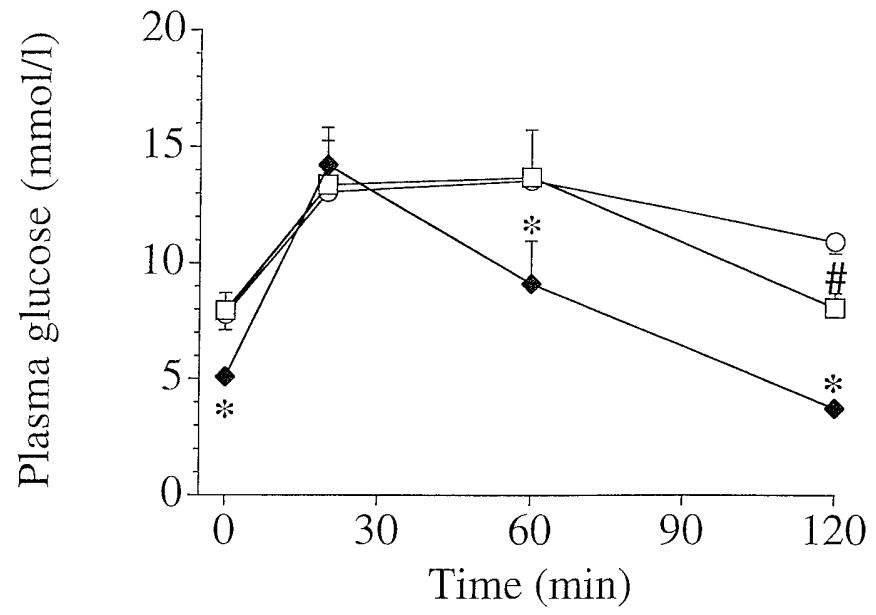

Fig. 3. Plasma glucose concentrations during meal challenges of STZ diabetic $\mathrm{B}_{6} \mathrm{AF}_{1}$ mice. The test was performed 9 weeks after i.p. transplantation of either microencapsulated xenogeneic rat islets $(\diamond)(n=7)$ or syngeneic non-encapsulated mouse islets $(\square)(n=5)$. As controls, age-matched normal non-diabetic $\mathrm{B} 6 \mathrm{AF}_{1}$ mice were used $(\bigcirc)(n=9)$. Data are presented as means $\pm \mathrm{SEM}$; ${ }^{*} p<0.02$ microcapsules vs normal and syngeneic, ${ }^{\#} p<0.001$ syngeneic vs normal

fasted blood glucose concentrations of $5.1 \pm$ $1.1 \mathrm{mmol} / \mathrm{l}$ whereas $\mathrm{SD}$ rats have $3.3 \pm 0.1 \mathrm{mmol} / \mathrm{l}$ and fed blood glucose concentrations of $6.9 \pm 0.2 \mathrm{mmol} / 1$ and $4.4 \pm 0.1 \mathrm{mmol} / 1$, respectively. We have reported previously similar results in Swiss Webster nude mice transplanted subcutaneously with macroencapsulated SD rat islets [22]. Despite the lower starting values, the peak glucose concentrations at 20 min were comparable to those of the other groups. Moreover, the microencapsulated group had a much faster rate of glucose clearance, with glucose concentrations decreasing to considerably lower values at $120 \mathrm{~min}$. In fact, for the 6 and 9 week groups, glucose concentrations were even lower than the fasting values, being about $3.6 \mathrm{mmol} / 1$ at $120 \mathrm{~min}$ compared with fasting values of about $5.0 \mathrm{mmol} / 1$.

Table 1. Plasma glucose after meal challenge in $\mathrm{STZ}$ diabetic $B 6 \mathrm{AF}_{1}$ mice transplanted with microencapsulated xenogeneic islets

\begin{tabular}{|c|c|c|c|c|c|c|c|}
\hline \multirow[t]{2}{*}{ Groups } & \multirow[t]{2}{*}{$\begin{array}{l}\text { Weeks } \\
\text { after Tx }\end{array}$} & $0 \mathrm{~min}$ & $20 \mathrm{~min}$ & $60 \mathrm{~min}$ & $120 \mathrm{~min}$ & \multirow{2}{*}{$\begin{array}{l}\text { Area under } \\
\text { the curve } \\
\mathrm{mmol} \cdot \mathrm{min} / \mathrm{l}\end{array}$} & \multirow[t]{2}{*}{$\begin{array}{l}\text { Number } \\
\text { of animals }\end{array}$} \\
\hline & & $\mathrm{mmol} / \mathrm{l}$ & & & & & \\
\hline Syngeneic & $\begin{array}{l}3 \\
6 \\
9\end{array}$ & $\begin{array}{l}6.7 \pm 0.6 \\
6.2 \pm 0.6 \\
8.2 \pm 0.7\end{array}$ & $\begin{array}{l}12.5 \pm 1.2 \\
12.8 \pm 1.1 \\
14.0 \pm 1.6\end{array}$ & $\begin{array}{r}9.4 \pm 1.3 \\
11.0 \pm 1.0 \\
14.2 \pm 1.7\end{array}$ & $\begin{array}{l}6.7 \pm 0.6 \\
8.7 \pm 1.0 \\
8.1 \pm 0.5\end{array}$ & $\begin{array}{l}1154 \pm 115 \\
1189 \pm 67 \\
1456 \pm 118\end{array}$ & $\begin{array}{l}5 \\
5 \\
5\end{array}$ \\
\hline Normal & $\begin{array}{l}1 \\
6 \\
9\end{array}$ & $\begin{array}{l}5.6 \pm 0.4 \\
7.9 \pm 0.7 \\
7.8 \pm 0.7\end{array}$ & $\begin{array}{l}11.9 \pm 0.4 \\
11.3 \pm 0.3 \\
13.1 \pm 0.4\end{array}$ & $\begin{array}{r}9.4 \pm 2.1 \\
11.7 \pm 0.5 \\
13.6 \pm 0.4\end{array}$ & $\begin{array}{l}8.5 \pm 1.4 \\
9.6 \pm 0.4 \\
11.0 \pm 0.5\end{array}$ & $\begin{array}{l}1207 \pm 179^{c} \\
1292 \pm 29^{c} \\
1468 \pm 42\end{array}$ & $\begin{array}{l}9 \\
9 \\
9\end{array}$ \\
\hline
\end{tabular}

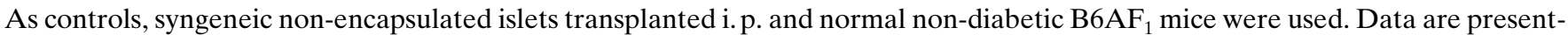
ed as means \pm SEM; ${ }^{a} p<0.01$ vs normal at 6 weeks, ${ }^{\mathrm{b}} p<0.02$ vs syngeneic and normal at 9 weeks, ${ }^{\mathrm{c}} p<0.05$ vs normal at 9 weeks 
Table 2. Plasma $\mathrm{C}$ peptide after meal challenge in $\mathrm{STZ}$ diabetic $\mathrm{B}_{\mathrm{A}} \mathrm{AF}_{1}$ mice transplanted with microencapsulated xenogeneic islets

\begin{tabular}{|c|c|c|c|c|c|c|c|}
\hline \multirow[t]{2}{*}{ Groups } & \multirow[t]{2}{*}{$\begin{array}{l}\text { Weeks } \\
\text { after Tx }\end{array}$} & $0 \min$ & \multirow[t]{2}{*}{$20 \mathrm{~min}$} & \multirow[t]{2}{*}{$60 \mathrm{~min}$} & \multirow[t]{2}{*}{$120 \mathrm{~min}$} & \multirow{2}{*}{$\begin{array}{l}\begin{array}{l}\text { Area under } \\
\text { the curve }\end{array} \\
\mathrm{pmol} \cdot \mathrm{min} / 1 \\
\text { (thousands) }\end{array}$} & \multirow[t]{2}{*}{$\begin{array}{l}\text { Number } \\
\text { of animals }\end{array}$} \\
\hline & & $\mathrm{pmmol} / 1$ & & & & & \\
\hline Microencapsules-xeno & $\begin{array}{l}3 \\
6 \\
9\end{array}$ & $\begin{array}{l}58 \pm 19 \\
86 \pm 15 \\
91 \pm 22\end{array}$ & $\begin{array}{l}117 \pm 18^{a} \\
127 \pm 31 \\
132 \pm 20\end{array}$ & $\begin{array}{l}239 \pm 43 \\
258 \pm 38 \\
259 \pm 38\end{array}$ & $\begin{array}{l}174 \pm 43 \\
238 \pm 26 \\
236 \pm 47\end{array}$ & $\begin{array}{l}21.2 \pm 3.6 \\
24.7 \pm 2.8 \\
24.9 \pm 3.5\end{array}$ & $\begin{array}{l}6 \\
7 \\
7\end{array}$ \\
\hline Normal & $\begin{array}{l}1 \\
6 \\
9\end{array}$ & $\begin{array}{l}217 \pm 33 \\
297 \pm 36 \\
229 \pm 38\end{array}$ & $\begin{array}{l}426 \pm 143 \\
582 \pm 39 \\
571 \pm 68\end{array}$ & $\begin{array}{l}241 \pm 111 \\
407 \pm 28 \\
534 \pm 74\end{array}$ & $\begin{array}{l}199 \pm 40 \\
378 \pm 48 \\
562 \pm 98\end{array}$ & $\begin{array}{l}33.2 \pm 6.3 \\
52.1 \pm 3.1^{\mathrm{b}} \\
66.0 \pm 9.0^{\mathrm{cd}}\end{array}$ & $\begin{array}{l}9 \\
9 \\
9\end{array}$ \\
\hline
\end{tabular}

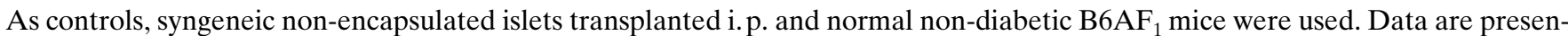
ted as means $\pm \mathrm{SEM} ;{ }^{\mathrm{a}} p<0.02$ vs microcapsules at $0 \mathrm{~min},{ }^{\mathrm{b}} p<0.01$ vs microcapsules and syngeneic at 6 weeks, ${ }^{\mathrm{c}} p<0.01 \mathrm{vs}$ microcapsules and syngeneic at 9 weeks, ${ }^{\mathrm{d}} p<0.02$ vs normal at 1 week

The group of mice with syngeneic islets in the peritoneal cavity had similar glucose profiles to control mice, except for faster glucose clearance as evidenced by lower glucose values at $120 \mathrm{~min}$ (at 9 weeks, $8.1 \pm 0.6$ versus $10.9 \pm 0.5 \mathrm{mmol} / 1 ; p<0.001)$.

The area under the plasma glucose curve was significantly lower for mice with microencapsulated rat islets at 6 and 9 weeks compared to normal controls $(p<0.02)$ and at 9 weeks compared with the group transplanted with syngeneic islets. This difference is largely accounted by the decreased glucose concentrations found at 0,60 and $120 \mathrm{~min}$. In all three groups there was a tendency for the glucose AUC to increase from 3 to 9 weeks.

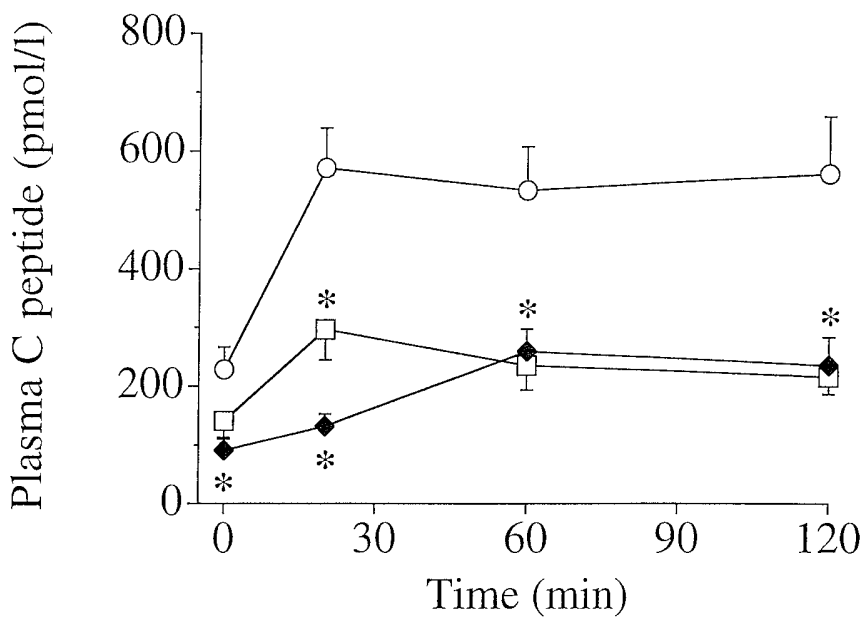

Fig. 4. Plasma $\mathrm{C}$ peptide concentrations during a meal challenge of STZ diabetic $\mathrm{B} \mathrm{AF}_{1}$ mice. The test was done 9 weeks after i.p. transplantation of either microencapsulated xenogeneic rat islets $(\bullet)(n=7)$ or syngeneic non-encapsulated islets $(\square)(n=5)$. As controls, age-matched normal non-diabetic $\mathrm{B} 6 \mathrm{AF}_{1}$ mice were used $(\bigcirc)(n=9)$. Data are presented as means \pm SEM; ${ }^{*} p<0.01$ microcapsules and syngeneic vs normal
$C$ peptide responses in vivo. Plasma $\mathrm{C}$ peptide values and AUCs from the meal challenges are shown in Table 2. Values for the 9 week point are depicted in Figure 4. For the group with encapsulated rat islets at 3,6 and 9 weeks, C peptide values at 20 min were higher than fasting values but significance was only found at 3 weeks $(58 \pm 19$ rising to $117 \pm 18 \mathrm{pmol} / \mathrm{l}$, $p<0.02$ ). Unambiguous increases in this group were found at 60 and $120 \mathrm{~min}$ at all three time points after transplantation. Notably, the responses of the group with encapsulated islets were considerably slower than in the other two groups, with this being most obvious at the 20 min time point. It should be noted that the $\mathrm{C}$ peptide responses of the mice with naked syngeneic islets in the peritoneal cavity were clearly lower than those of control mice. This was surprising because the glucose clearance was faster in spite of these lower $\mathrm{C}$ peptide values, while the glucose values at 120 min were significantly lower at the 6 and 9 week time points (Table 1). When the AUCs of the $\mathrm{C}$ peptide responses were analysed, the values for the microencapsulated rat islet group and naked syngeneic islet group were similar. However, the AUCs for the $\mathrm{C}$ peptide responses of the normal mice were about twice as high as those of the two transplanted groups.

Insulin secretion in vitro. A glucose concentration of $5.6 \mathrm{mmol} / \mathrm{l}$ was used as a basal concentration prior to high glucose stimulation, since plasma concentrations found after overnight fasting in rodents were approximately in this order of magnitude. Microencapsulated rat islets cultured for 4 days responded to the high glucose stimulus; insulin release rose from $41 \pm 8 \mathrm{pg} \cdot$ islet $^{-1} \cdot \mathrm{h}^{-1}$ in the basal state to $150 \pm 40$ $\mathrm{pg} \cdot$ islet $^{-1} \cdot \mathrm{h}^{-1}$ with $16.7 \mathrm{mmol} / \mathrm{l}$ glucose, and to $531 \pm 70 \mathrm{pg} \cdot$ islet $^{-1} \cdot \mathrm{h}^{-1}$ with $16.7 \mathrm{mmol} / \mathrm{l}$ glucose and $10 \mathrm{mmol} / \mathrm{l}$ theophylline (Fig. 5). The amount of se- 

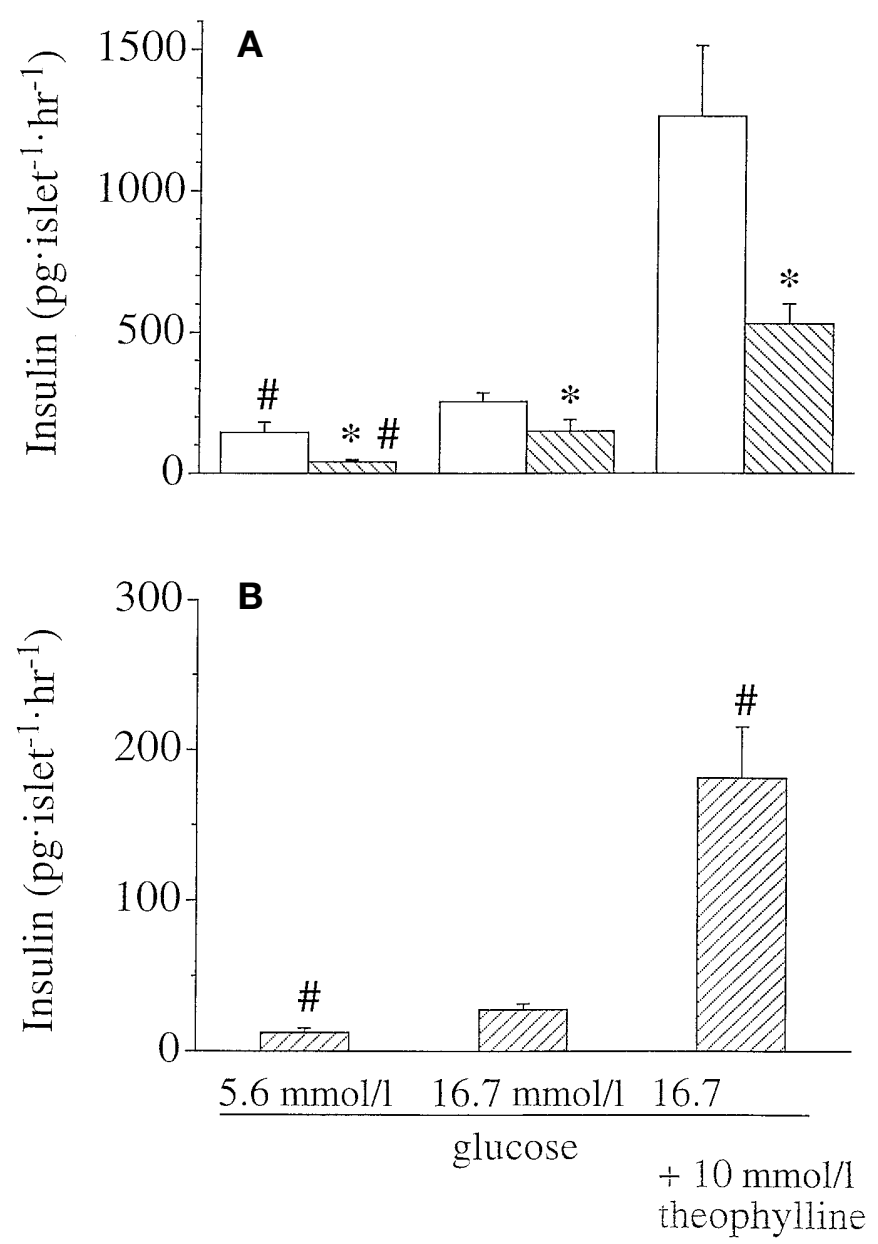

Fig. 5 (A, B). Glucose-induced insulin release by microencapsulated (․․․) and non-encapsulated $(\square)$ rat islets cultured for 5 days $(\mathbf{A})$, and by microencapsulated rat islets retrieved ( $)$ from STZ diabetic $\mathrm{B}_{6} \mathrm{AF}_{1}$ after being transplanted for 9 weeks (B) (Please note the difference in scale). Data are presented as means from 2-4 separate experiments done in triplicates \pm SEM; ${ }^{*} p<0.01$ microencapsulated vs non-encapsulated, ${ }^{\#} p<0.05$ vs. secretion at $16.7 \mathrm{mmol} / 1$ glucose from the same group

creted insulin, however, was substantially lower than that secreted by control non-encapsulated rat islets, which increased from a basal concentrations of $144 \pm 36$ to $254 \pm 32 \mathrm{pg} \cdot$ islet $^{-1} \cdot \mathrm{h}^{-1}$ in the presence of high glucose. A further increase was found in the combined presence of glucose and theophylline. Microencapsulated rat islets retrieved 9 weeks after transplantation did not lose their ability to respond to either glucose or theophylline, but their output was less than half of encapsulated islets cultured for 4 days.

\section{Discussion}

Little information is available about the in vivo dynamics and quantity of insulin release from encapsulated islets. Our study provides information about the delivery of $\mathrm{C}$ peptide from microencapsulated rat islets into the peripheral circulation of mice. We conclude that the delivery of $\mathrm{C}$ peptide and presumably the delivery of insulin, which accompanies $\mathrm{C}$ peptide with equimolar quantities, are delayed by restrictions of the capsules and the peritoneal location. That delay in reaching peripheral target organs does not prevent these grafts from being efficient enough to maintain normal glucose concentrations.

We found at 3 weeks after transplantation, a significant increase of $\mathrm{C}$ peptide released from microcapsules at the 20 min time point, although the increases at 6 and 9 weeks did not reach statistical significance. Clear statistical significance was found 40 min later in all groups. These data suggest that some release occurs before 20 min, which might have more important effects upon liver than muscle. Much more release occurs after $20 \mathrm{~min}$ and it seems likely that samples taken at the 30 min point would have shown statistically significant increases. The question arises as to how much insulin effect might be exerted during the 10 to $20 \mathrm{~min}$ period, compared with later periods. Perhaps the rat islets used in this study are uniquely sensitive to gut hormones released from mice during a meal. Unfortunately, it was not feasible to carry out intravenous challenges with glucose or other secretagogues such as arginine or glucagon-like peptide 1 (GLP-1) because of the small size of the mice.

When $C$ peptide and insulin released in the peritoneal cavity enter the portal circulation, a large portion of the insulin is taken up by the liver, while $\mathrm{C}$ peptide is hardly extracted at all. Therefore, in our previous study, insulin could have been released and exerted important effects on the liver but have been difficult to measure in peripheral plasma. This explanation might be supported by the fact that intraperitoneal insulin infusions mimicking insulin release from capsules were associated with only modest insulin increases in systemic circulation, and delayed glucose clearance [14].

Similarly, in diabetic mice transplanted with islets encapsulated in hollow fibers, glucose concentrations were normalized, but peripheral insulin concentrations were low and did not increase after glucose challenges [23]. We have also observed rapid glucose clearance in rats with alginate macrobeads (about $3 \mathrm{~mm}$ in diameter) containing syngeneic islets, but found no measurable increases in circulating insulin concentrations after challenges with intravenous glucose, arginine and GLP-1 [24]. In contrast, modest and delayed increases of insulin concentrations were found after meal challenges. We concluded that much of the restriction was due to the long time required for diffusion out of such large capsules.

Studies on encapsulation within smaller microcapsules (diameter $250-350 \mu \mathrm{m}$ ) or by conformal coating (50 $\mu \mathrm{m}$ layer) resulted in fast glucose clearance during glucose tolerance tests in mice transplanted with 
porcine islets [25, 26]. Another study, however, showed completely normal oral glucose tolerance test in rats with pig islets in conformal microcapsules [27]. Neither insulin nor C peptide data were reported in these papers.

Studies in larger animals do not provide much additional information. A previous study reported that in monkeys transplanted with microencapsulated porcine islets, intravenous glucose challenges were accompanied by about a threefold increase in insulin concentrations but some of the insulin might have been from residual beta cells in the monkeys' pancreata. These responses were not compared with normal control monkeys [11]. In a study of diabetic dogs transplanted with canine islets in relative large microcapsules, C peptide results were limited to one dog, but the $\mathrm{C}$ peptide response gradually increased for the 60 min after the intravenous glucose challenge [10]. In other dog experiments, a flat shaped dose-response curve for $\mathrm{C}$ peptide was found after the administration of intravenous glucose [9].

In attempts to understand the dynamics of insulin release from encapsulated islets, investigators have often looked at the rate of release with in vitro experiments. Unfortunately, these kinds of studies are not likely to provide useful insights into what is happening in vivo. Rapid release of insulin has been found when either microencapsulated or macroencapsulated islets were perifused $[5,28]$ but the movement of fluid on the surface of the capsules during perifusion would be expected to markedly accelerate the movement of insulin from inside the capsules. The size of capsules should be associated with the rate of insulin release as can be predicted by the laws of diffusion $[29,30]$.

Many questions can be posed about the peritoneal site as a location for either naked or encapsulated islets. In the present experiments, the $\mathrm{C}$ peptide concentrations in plasma were considerably decreased in the groups with either naked or encapsulated islets in the peritoneal cavity than in the control mice. Surprisingly, glucose clearance was about the same for these transplanted mice although $\mathrm{C}$ peptide concentrations were half of those of the controls.

One possible explanation is that the peritoneal cavity is known to be less accommodating to transplanted islets. It has been found that naked syngeneic islets transplanted under the kidney capsule or into the portal vein of diabetic rats were much more efficient in normalizing glucose concentrations than when transplanted into the peritoneal cavity [31-33]. Additionally, islets in microcapsules are possibly exposed to relative hypoxia because of lack of vascularization in peritoneal space. Of note, mice in this study received 1000 syngeneic islets whereas only 400 are usually required to normalize glucose concentrations when placed under the kidney capsule [34]. We have shown previously that about $40 \%$ of encapsulated islets are lost after transplantation [35].
The differences in body weight among the groups are potentially important. In spite of a rapid increase in weight in the two weeks after transplantation, the mice with encapsulated rat islets remained substantially lighter than the normal control rats. Even the mice with syngeneic islets in the peritoneal cavity became lighter than the control mice. Similar limitation in weight gain compared with controls was observed in rats transplanted with microencapsulated or naked islets $[12,33]$. It is also possible that the presence of substantial volume of capsules in peritoneal cavity led to a loss in appetite. During these studies, food uptake was not measured but the experimental animals looked and behaved normally. Inflammation caused by the encapsulated islets could cause appetite problems but the majority of retrieved microcapsules were free of overgrowth and macroscopic evaluation did not show any signs of inflammation in the peritoneal membranes. An alternative explanation might be that the difference in body weight is caused by the substantially lower insulin amount in the systemic circulation of transplanted animals when compared to normal controls [35]. The decreased insulin concentration in the transplanted animals is adequate to provide optimal glucose clearence but it could be too low to completely abolish lipolysis between meals. By transplanting more islets, in order to account for the loss of functional islets associated with the isolation and transplantation procedures [35], we could increase the systemic insulin concentrations and thereby correct the differences in body weight.

Results obtained in free-feeding caged rodents might not allow us to fully understand the requirements for humans, who must be able to change insulin delivery to accommodate intermittent meals, overnight fasts and the challenges of exercise. It is known from experience with pump delivery of insulin in patients with Type I diabetes, that a constant rate of delivery of insulin will not provide adequate control of blood glucose concentrations. Satisfactory control can only be obtained if insulin is provided for meals and adjustments in delivery are made during an overnight fast. It seems likely based upon work with mechanical artificial pancreases that delays of insulin release of 10 to $15 \mathrm{~min}$ could be tolerable [36]. In conclusion, we suggest that the dynamics of insulin release from microencapsulated islets in the peritoneal cavity could be rapid enough to meet the demands of a normal lifestyle in humans.

Acknowledgements. The authors appreciate the expert technical assistance of J. Lock. This work was supported by grants from the National Institutes of Sciences (DK 50657 to GCW), the Juvenile Diabetes Foundation International (JDFI), the JDFI Center for Islet Transplantation at Harvard Medical School and an important group of private donors. The core facilities for animal care were supported by National Institutes of Health Grant DK-36836 (the Diabetes Endocrinology Research Center of the Joslin Diabetes Center). 


\section{References}

1. O'Shea GM, Sun AM (1986) Encapsulation of rat islets of Langerhans prolongs xenograft survival in diabetic mice. Diabetes 35: 943-946

2. Fan M-Y, Lum Z-P, Fu X-W, Levesque L, Tai IT, Sun AM (1990) Reversal of diabetes in BB rats by transplantation of encapsulated pancreatic islets. Diabetes 39: 519-522

3. Iwata H, Amemiya H, Matsuda T, Takano H, Hayashi R, Akutsu T (1989) Evaluation of microencapsulated islets in agarose gel as bioartificial pancreas by studies of hormone secretion in culture and by xenotransplantation. Diabetes 38 [Suppl 1]: 224-225

4. Calafiore R, Basta G, Luca G et al. (1997) Alginate/polyaminoacidic coherent microcapsules for pancreatic islet graft immunoisolation in diabetic recipients. Ann NY Acad Sci 831: 313-322

5. Lanza RP, Kugtreiber WM, Ecker D, Staruk JE, Chick WL (1995) Xenotransplantation of porcine and bovine islets without immunosuppression using uncoated alginate microspheres. Transplantation 59: 1377-1384

6. Weber CJ, Hagler MK, Chryssochoos JT et al. (1997) CTLA4-Ig prolongs survival of microencapsulated neonatal porcine islet xenografts in diabetic NOD mice. Cell Transplant 6: 505-508

7. Zekorn TDC, Horcher A, Siebers U, Federlin K, Bretzel RG (1999) Synergistic effect of microencapsulation and immunoalteration on islet allograft survival in bioartificial pancreas. J Mol Med 77: 193-198

8. Jain K, Asina S, Yang H et al. (1999) Glucose control and long-term survival in Bio Breeding/Worcester rats after intraperitoneal implantation of hydrophilic macrobeads containing porcine islets without immunosuppression. Transplantation 68: 1693-1700

9. Soon-Shiong P, Feldman E, Nelson R et al. (1992) Successful reversal of spontaneous diabetes in dogs by intraperitoneal microencapsulated islets. Transplantation 54: 769-774

10. Lanza RP, Ecker DM, Kuhtreiber WM, Marsh JP, Ringeling J, Chick WL (1999) Transplantation of islets using microencapsulation: studies in diabetic rodents and dogs. J Mol Med 77: 206-210

11. Sun A, Ma X, Zhou D, Vacek I, Sun AM (1996) Normalization of diabetes in spontaneously diabetic cynomologus monkeys by xenografts of microencapsulated porcine islets without immunosuppression. J Clin Invest 98: 1417-1422

12. Fritschy WM, Strubbe JH, Wolters GHJ, van Schilfgaarde R (1991) Glucose tolerance and plasma insulin response to intravenous glucose infusion and test meal in rats with microencapsulated islet allografts. Diabetologia 34: 542-547

13. De Vos P, De Haan BJ, Wotlers GHJ, Strubbe JH, van Schilfgaarde R (1997) Improved biocompatibility but limited graft survival after purification of alginate for microencapsulation of pancreatic islets. Diabetologia 40: 262-270

14. De Vos P, Vegter D, De Haan BJ, Strubbe JH, Bruggink JE, van Schilfgaarde R (1996) Kinetics of intraperitoneally infused insulin in rat. Functional implications for the bioartificial pancreas. Diabetes 45: 1102-1107

15. Ar'Rajab A, Bengmark S, Ahren B (1991) Insulin secretion in streptozotocin-diabetic rats transplanted with immunoisolated islets. Transplantation 51: 570-574

16. Polonsky KS, Pugh W, Jaspan JB et al. (1984) C-peptide and insulin secretion. Relationship between peripheral concentrations of C-peptide and insulin and their secretion rates in the dog. J Clin Invest 74: 1821-1829

17. Weitgasser R, Davalli AM, Weir GC (1999) Measurement of glucose concentrations in rats: differences between glucose meter and plasma laboratory results. Diabetologia 42: 256-261
18. Gotoh M, Maki T, Kiyoizumi T, Satomi S, Monaco AP (1985) An improved method for isolation of mouse pancreatic islets. Transplantation 40: 437-438

19. De Vos P, De Haan B, Wolters GHJ, van Schilfgaarde R (1996) Factors influencing the adequacy of microencapuslation of rat pancreatic islets. Transplantation 62: 888-893

20. De Vos P, De Haan B, Pater J, van Schilfgaarde R (1996) Association between capsule diameter, adequacy of encapsulation, and survival of microencapuslated rat islet allografts. Transplantation 62: 893-899

21. Feng S, Quickel RR, Hollister-Lock J et al. (1999) Prolonged xenograft survival of islets infected with small doses of adenovirus containing CTLA4Ig. Transplantation 67: 1607-1613

22. Tatarkiewicz K, Hollister-Lock J, Quickel RR, Colton CK, Bonner-Weir S, Weir GC (1999) Reversal of hyperglycemia in mice after subcutaneous transplantation of macroencapsulated islets. Transplantation 67: 665-671

23. Delaunay C, Darquy S, Honiger J, Capron F, Rouault C, Reach G (1998) Glucose-insulin kinetics of a bioartificial pancreas made of an AN69 hydrogel hollow fiber containing porcine islets and implanted in diabetic mice. Artif Organs 22: 291-299

24. Trivedi N, Keegan M, Steil GM et al. (2001) Islets in alginate macrobeads reverse diabetes despite minimal acute insulin secretory responses. Transplantation 71: 203-211

25. Rayat GR, Rajotte RV, Ao Z, Korbutt GS (2000) Microencapsulation of neonatal porcine islets: Protection from human antibody/complement-mediated cytolysis in vitro and long-term reversal of diabetes in nude mice. Transplantation 69: 1084-1090

26. Cruise GM, Hegre OD, Lamberti FV et al. (1999) In vitro and in vivo performance of porcine islets encapsulated in interfacially photopolymerized poly(ethylene glycol) diacrylate membranes. Cell Transplant 8: 293-306

27. Hill RS, Cruise GM, Hager SR et al. (1997) Immunoisolation of adult porcine islets for the treatment of diabetes mellitus. Ann NY Acad Sci 831: 332-343

28. Lum ZP, Tai IT, Krestow M, Norton J, Vacek I, Sun AM (1991) Prolonged reversal of diabetic state in NOD mice by xenografts of microencapsulated rat islets. Diabetes 40: $1511-1516$

29. Chicheportiche D, Reach G (1988) In vitro kinetics of insulin release by microencapsulated rat islets: effect of the size of the microcapsules. Diabetologia 31: 54-57

30. Wang T, Lacik I, Brissova M et al. (1997) An encapsulation system for the immunoisolation of pancreatic islets. Nat Biotechnol 15: 358-362

31. Okugawa K, Fukuda Y, Sakimoto H et al. (1996) Intermittent intraperitoneal implantation of islets in rat islet transplantation. Cell Transplant 5 [Suppl 1]: S51-S53

32. Kemp CB, Knight MJ, Scharp DW, Ballinger WF, Lacy PE (1973) Effect of transplantation site on the results of pancreatic islet isografts in diabetic rats. Diabetologia 9: 486-491

33. Fritschy WM, Van Straaten JFM, De Vos P, Strubbe JH, Wolters GHJ, van Schilfgaarde R (1991) The efficacy of intraperitoneal pancreatic islet isografts in the reversal of diabetes in rats. Transplantation 52: 777-783

34. Davalli AM, Scaglia L, Zangen DH, Hollister J, Bonner-Weir S, Weir GC (1996) Vulnerability of islets in the immediate posttransplantation period. Diabetes 45: 1161-1167

35. De Vos P, Van Straaten JFM, Nieuwenhuizen AG et al. (1999) Why do microencapsulated islet grafts fail in the absence of fibrotic overgrowth. Diabetes 48: 1381-1388

36. Sorensen JT, Colton CK, Hillman RS, Soeldner JS (1982) Use of a physiologic pharmacokinetic model of glucose homeostatis for assessment of performance requirements for improved insulin therapies. Diabetes Care 5: 148-157 